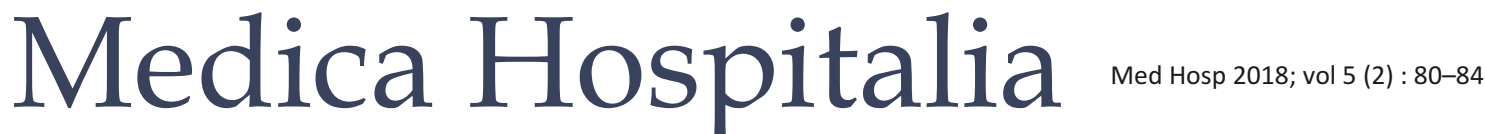

Original Article

\section{Korelasi antara Penambahan Berat Badan Janin dengan Asupan Protein Pada Kehamilan Trimester III}

\author{
Eva Martiana, Julian Dewantiningrum, Maria Mexitalia \\ Bagian Obstetri Ginekologi, Fakultas Kedokteran Universitas Diponegoro, Semarang, Indonesia
}

\begin{abstract}
Abstrak
Latar belakang : Kehamilan merupakan periode penting dalam pembentukan kualitas sumber daya manusia di masa yang akan datang. Asupan protein akan meningkatkan transpot asam amino ke dalam plasenta. Asam amino, khususnya arginin akan meningkatkan vasodilator NO sehingga akan meningkatkan transfer nutrisi ke janin. Selain itu, asupan protein yang cukup akan merangsang sekresi IGF-1 yang akan mendukung pertumbuhan janin. Di sisi lain, asupan protein yang berlebihan pada awal kehamilan merupakan faktor risiko terjadinya obesitas pada masa kanak-kanak yang dapat berlanjut menjadi penyakit jantung koroner dan sindroma metabolik pada saat dewasa. Faktor metabolik dan neuroendokrin yang berperan sejak masa kehamilan ini dikenal sebagai metabolic programming. Oleh karea itu perlu dilakukan penelitian awal untuk mengetahui korelasi antara penambahan berat badan janin dengan asupan protein pada kehamilan trimester 3. Penelitian ini bertujuan untuk membuktikan korelasi antara intake protein pada kehamilan Trimester III dengan penambahan berat badan janin intrauterin.

Metode : Penelitian ini adalah penelitian analitik observasional. Intake protein dinilai dengan metode food recall selama 24 jam dan dilakukan nutrisurvey untuk menilai kecukupan intake protein (cukup atau kurang). Penambahan berat badan janindinilai dengan menghitung selisih berat badan bayi saat lahir dengan berat janin pada usia kehamilan 30-34 minggu

Hasil : Sebanyak 42 subyek dilakukan food recall untuk mengetahui kecukupan protein pada kehamilan trimester III. Sebanyak 27 orang telah bersalin dan dinilai korelasi antara kecukupan intake protein dan penambahan berat badan janin. Hasil analisa didapatkan korelasi positif dengan derajat sedang antara penambahan berat badan janin dengan kecukupan protein pada kehamilan trimester III $(r 0,48 ; p 0,012)$.

Simpulan : Kecukupan intake protein pada kehamilan trimester III mempunyai korelasi dengan penambahan berat badan janin.
\end{abstract}

Kata kunci. : Kecukupan asupan protein, berat badan bayi, penambahan berat badan janin, food recall

\section{Correlation between fetal weight gain with protein consumption in third trimester}

\begin{abstract}
Background : Pregnancy is an important period for making a good quality of human resources in the future. In various ethnics and countries, epidemiological studies have shown that diet method that was used in sensitive periods from fetal phase to early life can produce a long-term effects. Excessive protein intake in early infancy is a risk factor for obesity in childhood that may develop to coronary heart disease and metabolic syndrome in adulthood. This eating behavior starts early, at the time of the pre-natal and breastfeeding period. Metabolic and neuroendocrine factors that takes role in fetal developmental since the time of fetal period is known as "metabolic programming". Fetal growth is largely determined by the nutrients that were transferred through the placenta, which is affected by both maternal nutrient levels and placental transport capacity. The objectives of this study was to investigate correlation between the adequacy of protein in third trimester of pregnancy with intrauterine fetal weight gain. Data was taken from 2 hospitals and 3 puskesmas (community health center), with varying HSP (Health Service Provider) from HSP I to HSP III (referral center), are expected to represent population variations.

Methods : We designed an observational analytic study to find a correlation between fetal weight gain, by calculating the differences between the estimated fetal weights that were measured in third trimester with the adequacy of protein in third trimester of pregnancy, using food recall method, and then followed up until the labor occurred.

Results : From 48 respondents, 6 was dropped out, and from 42 respondents remains, we did food recall to determine the adequacy of protein intake in the third trimester of pregnancy. There was 27 respondents that has reached birth. From the results of this study, we found a positive moderate correlation between fetal weight gain with the adequacy of protein intake in the third trimester, with the value of $r$ was 0,48 and $p$ was 0.012 .
\end{abstract}


Conclusion : In this study, there was a positive correlation between fetal weight gain with the adequacy of protein intake in third trimester.

Keywords : Adequacy of protein in third trimester, fetal weight, birth weight gain, food recall

\section{PENDAHULUAN}

Pada berbagai etnis dan negara, penelitian epidemiologis memperlihatkan bahwa pemberian diet pada periode sensitif sejak janin sampai masa awal kehidupan dapat menimbulkan dampak jangka panjang. Kenaikan berat badan yang cepat pada awal kehidupan dapat merangsang sistem metabolik dan menyebabkan obesitas dan penyakit tidak menular di kemudian hari yang dikenal dengan sindroma metabolik. ${ }^{1,2}$ Fenomena ini yang dikenal sebagai metabolic programming yang dikemukakan sejak lebih dari 30 tahun yang lalu oleh Gunter Donner dari Jerman. ${ }^{3}$ Beberapa hormon dan faktor pertumbuhan diketahui berperan penting dalam percepatan pertumbuhan, antara lain hormon pertumbuhan, insulin-like growth factor (IGF)-1 ${ }^{4}$ dan hormon leptin. ${ }^{5}$

Mengingat pentingnya jumlah dan jenis asupan protein ini pada masa prenatal dan post natal sejauh ini belum pernah dilakukan di Indonesia yang tentunya mempunyai perbedaan pola makanan dan lingkungan yang akan mempengaruhi asupan protein pada saat kehamilan trimester III. Transport asam amino yang terkandung pada protein melalui plasenta dipengaruhi oleh banyak faktor, terutama adalah intake ibu, penyakit ibu, infeksi, gen yang abnormal dan sebagainya. Arginin yang berasal dari protein akan menyebabkan peningkatan NO yang meningkatkan vasodilatasi pembuluh darah sehingga akan meningkatkan perfusi uteroplasenter. Peningkatan perfusi uteroplasenter akan mendukung transport nutrisi ke janin, sehingga terjadi pertumbuhan janin yang memadai. Asupan protein yang cukup akan merangsang sekresi IGF 1 yang mendukung pertumbuhanjanin intrauterin.,

Penelitian ini bertujuan untuk membuktikan adanya korelasi antara asupan protein pada usia kehamilan trimester III dengan penambahan berat badan janin intrauterin yang dinilai dengan pemeriksaan ultrasonografi (USG) biometri janin pada usia kehamilan trimester III.

\section{METODE}

\section{Rancangan penelitian}

Penelitian ini merupakan studi observasional analitik, merupakan bagian dari penelitian utama dengan judul "Pengaruh asupan protein ibu terhadap pertumbuhan janin intrauterin hingga 6 bulan pertama kehidupan : studi terhadap komposisi ASI, kadar IGF-1 dan Leptin" yang mendapat hibah IDAI-NIF 2017. Penelitian dilaksanakan selama 4 bulan yaitu awal Maret sampai dengan akhir Juni 2017. Lokasi penelitian adalah di kamar bersalin dari 2 rumah sakit dan 3 puskesmas, dengan bervariasi Pemberi Pelayanan Kesehatan (PPK) mulai dari PPK I sampai PPK III (pusat rujukan), diantaranya adalah Puskesmas Rowosari, Puskesmas Ngesrep, Puskesmas Halmahera, RSUP Dr. Kariadi dan RSNasional Diponegoro.

\section{Subyek penelitian}

Pemilihan subyek penelitian dilakukan secara purposive sampling. Subyek penelitian adalah ibu hamil yang pada periode penelitian menjalankan pemeriksaan ante natal oleh bidan yang berada padaPPK di wilayah penelitian yang memenuhi kriteria inklusi yaitu kehamilan normal 30-34 minggu, janin tunggal, intrauterin dan usia ibu saat hamil < 40 tahun. Subyek yang menderita pre eklampsia/eklampsia, menderita diabetes melitus atau gestational diabetes melitus, mempunyai riwayat hipertensi dan kadar $\mathrm{Hb}<7 \mathrm{gr} / \mathrm{dL}$ dan yang tidak bersedia,tidak diikutsertakan dalam penelitian. Subyek yang pada periode penelitian pindah dari wilayah PPK lokasi penelitian dan tidak bersedia melanjutkan penelitian atau menderita sakit atau meninggal saat pengamatan dinyatakan sebagai drop-out.

\section{Pelaksanaan penelitian}

Data ibu hamil yang dikumpulkan adalah data antropometri meliputi Berat Badan (BB), Tinggi Badan (TB), Taksiran Berat Janin (TBJ) dan berat bayi lahir (BBL). Penilaian TBJ berdasarkan USG biometri janin pada trimester III. Status gizi subjek diukur menggunakan indikator Indeks Massa Tubuh (IMT) pra-hamil dan kenaikan berat badan hamil ibu dihitung dengan menggunakan formulasi estimasi berdasarkan dua data berat badan hamil dengan selang waktu pengukuran minimal 11 minggu. Penimbangan berat badan ibu hamil menggunakan timbangan digital dengan tingkat ketelitian 0,1 kg. Penimbangan berat badan bayi menggunakan infant scale.

Variabel bebas adalah intake protein yang diperoleh dengan menggunakan metode food recall 24 jam kemudian dianalisis menggunakan software Nutrisurvey (http://www.nutrisurvey.de). Penilaian intake protein dinilai kurang bila $<100 \%$ dan dinilai cukup bila antara $100-120 \%$. Variabel tergantung adalah penambahan 
berat badan janin yang merupakan selisih antara TBJ dengan BBL.

Sebanyak 27 subyek telah melahirkan dari total 42 subyek yang dilakukan food recall. Analisis data untuk mencari korelasi dilakukan pada 27 subyek tersebut, dan telah menandatangani informed consent untuk ikut serta dalam penelitian ini terlebih dahulu. Penelitian ini telah terdaftar di Komisi Etik Penelitian Kesehatan Fakultas Kedokteran Universitas Diponegoro-RSUP Dr. Kariadi Semarang, dengan nomor Ethical Clearance: 18/EC/FK-RSDK/1/2017.

\section{Analisis data}

Data yang berskala kategorial dideskrisikan sebagai distrbusi frekuensi dan persentase. Data yang berskala kontinyu dideskrisikan sebagai rerata \pm Simpang Baku (SB), median dan rentang minimal (min) maksimal (maks). Korelasi antara asupan protein pada usia kehamilan trimester III dengan penambahan berat badan janin intrauterin menggunakanuji korelasi Spearman.

\section{HASIL}

Total subjek sampai periode penelitian ini berjumlah 48 ibu hamil, 6 diantaranya drop out dengan alasanpindah keluar kota, tidak dapat dihubungi dan tidak diijinkan suami.

Karakteristik subyek penelitian ditampilkan pada tabel 1. Hasil penelitian ini menunjukkan rerata usia responden adalah 28,5 $\pm 5,94$ tahun, dengan umur termuda adalah 17 tahun dan tertua adalah 39 tahun. Rentang usia yang terbanyak adalah kelompok usia 25-29 tahun $(47,6 \%)$. Rerata IMT adalah 25,8 $\pm 3,26$ dengan nilai terendah BMI adalah 20,6 dan tertinggi 34,63 . Rata-rata paritas $1,8 \pm 0,80$ dengan jumlah anak paling sedikit adalah 1 anak dan terbanyak adalah 4 anak. Berdasarkan kategori jumlah anak sebagian besar responden memiliki lebih dari satu anak (54,2\%). Rerata taksiran berat badan janin saat USG trimester III adalah $2026,5 \pm 341,22$ gram dan rata-rata berat badan lahir adalah 3087 gram.

Kategori konsumsi protein ibu hamil pada usia kehamilan trimester III disajikan pada gambar 1 . Berdasarkan data pada gambar 1 dijumpai bahwa sebanyak sebagian besar subyek (81,0\%) mengkonsumsi protein kurang, subyek dengan kategori cukup asupan protein hanya $19 \%$.

Hasil uji korelasi antara berat badan janin dengan kecukupan protein ditampilkan pada tabel 2.

Hasil uji korelasi menunjukkan korelasi positif derajat sedang $(\mathrm{r}=0,48)$ yang bermakna antara berat badanjanin dengan kecukupan protein $(p=0,012)$.

\section{DISKUSI}

Pada penelitian ini dijumpai sebagian besar ibu hamil memiliki kecukupan asupan protein termasuk dalam kategori kurang. Di negara berkembang, termasuk

\section{TABEL 1}

\section{Karakteristik subjek}

\begin{tabular}{lcc} 
Variabel $\mathbf{( n = 4 2 )}$ & $\mathbf{n}$ & $(\%)$ \\
\hline $\begin{array}{l}\text { Usia (tahun) } \\
\leq 19\end{array}$ & 1 & $(2,4)$ \\
$20-24$ & 7 & $(16,7)$ \\
$25-29$ & 20 & $(47,6)$ \\
$30-34$ & 2 & $(4,8)$ \\
$\geq 35$ & 12 & $(28,6)$
\end{tabular}

IMT

Rerata \pm SB

(Min - Maks)

$<25$

20

25-29,99

16

$\geq 30$

6

Paritas
$28,5 \pm 5,94$

$(17-39)$

$25,8 \pm 3,26$

$(20,6-34,63)$

$1,8 \pm 0,80$

$(1-4)$

$53,3 \pm 16,29$

$(19,8-100,3)$

$79,2 \pm 24,53$

$(31,0-140,0)$ 


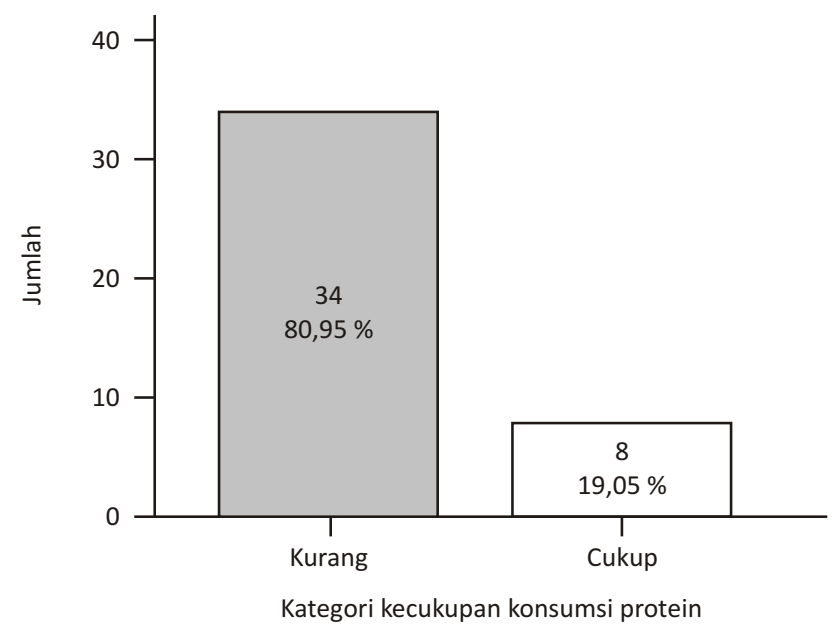

Gambar 1. Kategori konsumsi protein ibu hamil pada usia kehamilan trimester ketiga $(n=42)$

\section{TABEL 2}

Korelasi antara berat badan janin dengan kecukupan protein

\begin{tabular}{|c|c|c|c|c|c|}
\hline Variabel $(n=27)$ & $\mathbf{n}$ & $\%$ & Rerata \pm SD & Koefisien korelasi§ & $\mathbf{P}$ \\
\hline Selisih berat badan janin ${ }^{\S}$ & 27 & 27 & $1065,4 \pm 417,35$ & 0,48 & 0,012 \\
\hline Berat badan lahir & 27 & 27 & $3071,4 \pm 236,49$ & & \\
\hline Kecukupan protein & & & $79,2 \pm 24,53$ & & \\
\hline
\end{tabular}

Indonesia masalah gizi masih merupakan masalah kesehatan masyarakat yang utama. Masalah gizi merupakan penyebab tidak langsung terjadinya kematian ibu dan anak yang sebenarnya dapat dicegah. Rendahnya status gizi ibu hamil selama kehamilan dapat mengakibatkan berbagai dampak tidak baik bagi ibu dan bayi, diantaranya adalah bayi lahir dengan berat badan lahir rendah (BBLR). Kehamilan merupakan periode penting dalam pembentukan kualitas sumber daya manusia di masa yang akan datang. Pertumbuhan, perkembangan serta kesehatan anak sangat ditentukan oleh kondisi janin saat didalam kandungan. Berat badan lahir normal merupakan cerminan dan titik awal yang penting karena dapat menentukan kemampuan bayi dalam menyesuaikan diri terhadap lingkungan hidup yang baru sehingga tumbuh kembang bayi akan berlangsung secara normal. ${ }^{2}$

Beberapa faktor yang mempengaruhi ukuran bayi pada waktu lahir, salah satunya asupan gizi ibu selama kehamilan. Terdapat hubungan yang jelas antara konsumsi protein ibu pada bulan terakhir kehamilan dengan ukuran bayi pada saat lahir. Semakin buruk gizi ibu semakin kurang berat lahir dan panjang bayinya. Selain itu defisiensi mineral pada ibu selama kehamilan disebutkan juga mempunyai efek terhadap perkembangan pasca lahir yaitu kerusakan fungsi neurologis dan imunologis pada bayi. ${ }^{3}$ Asupan protein yang berlebihan pada awal masa bayi merupakan faktor risiko terjadinya obesitas pada masa kanak-kanak yang dapat berlanjut menjadi penyakit jantung koroner dan sindroma metabolik pada saat dewasa. Perilaku makan ini bahkan dimulai saat dini yaitu saat pre-natal dan periode menyusui. Faktor metabolik dan neuroendokrin yang berperan sejak masa fetus (janin) ini dikenal sebagai metabolic programming. 4

Rekomendasi asupan protein pada kehamilan adalah sebesar +25 gram per hari, atau 71 gram setiap harinya, dan sebanyak 1,1 gram/kg BB, untuk wanita usia 14 ke atas. Adaptasi fisiologis pada metabolisme protein selama kehamilan bergeser ke arah bertemunya keperluan protein bagi ibu dan janin. Kebutuhan protein bertambah selama kehamilan, utamanya dikarenakan bertambahnya protein jaringan. Dari sekitar 925 gram protein ( 2 pon) diakumulasikan pada protein jaringan selama kehamilan, 440 gram diambil oleh janin, 216 gram digunakan untuk menambah darah ibu dan volume cairan ekstraseluler, 166 gram dikonsumsi oleh uterus, dan 100 gram diakumulasikan oleh plasenta. Suplementasi protein tidak bermanfaat pada perjalanan atau keluaran kehamilan pada wanita yang cukup gizi. ${ }^{5}$

Pertumbuhan janin sangat ditentukan oleh transfer nutrien melalui plasenta yang dipengaruhi oleh kadar nutrien maternal maupun kapasitas transpor plasenta. Beberapa hormon seperti insulin, leptin, dan 
IGF-1 berperan dalam meningkatkan transpor nutrien ini. ${ }^{6}$ Penelitian di Pakistan menunjukkan bahwa IGF-1 plasenta pada bayi kecil masa kehamilan (KMK) lebih rendah dibanding bayi sesuai masa kehamilan (SMK), perawakan ibu yang kecil mempunyai kadar IGF-1 yang rendah dan kadar IGF-1 berhubungan dengan panjang badan bayi, ${ }^{7}$ tetapi beberapa penelitian lain menunjukkan ketidaksesuaian antara IGF-I tali pusat dengan perkiraan berat janin (fetus) yang diukur berdasarkan ultrasonografi, ${ }^{8}$ maupun dengan berat lahir bayi. ${ }^{9,10}$ Hormon lain yang dikaitkan dengan metabolic programming adalah adiponektin yang akan menurun jumlahnya pada obesitas. ${ }^{6}$

Penelitian ini merupakan penelitian pertama di Indonesia yang menilai kecukupan intake protein dengan penambahan berat badan janin. Kelemahan dari penelitian ini adalah jumlah sampel yang terbatas sehingga belum dapat mewakili seluruh populasi ibu hamil. Hal ini dikarenakan waktu pengumpulan data yang dilakukan dalam waktu yang relatif singkat yaitu hanya dalam waktu 4 bulan. Selain itu data faktor-faktor lain yaitu latar belakang etnis, sosial-ekonomi, pengetahuan tentang asupan protein selama kehamilan dan faktor-faktor lain yang dapat berpengaruh terhadap asupan protein belum dinilai. Penelitian lanjutan dengan sampel yang lebih besar dan variabel-variabel yang lebih lengkap khususnya tentang faktor-faktor yang dapat berpengaruh terhadap pertumbuhan janin dan asupan protein diperlukan untuk memberikan penjelasan lebih lanjut tentang hasil penelitian ini.

\section{SIMPULAN}

Kecukupan intake protein pada kehamilan trimester III mempunyai korelasi dengan penambahan berat badan janin. Untuk mendapatkan hasil yang lebih mewakili populasi ibu hamil, sebaiknya pada penelitian selanjutnya jumlah sampel, variabel dari faktor-faktor yang berpengaruh terhadap pertumbuhan dan asupan protein pada ibu hamil agar diperluas lagi.

\section{DAFTAR PUSTAKA}

1. Gibney MJ, Lanham-New SA, Cassidie A, Vorster HH. Introduction to human nutrition. $2^{\text {nd }} \mathrm{Ed}$. Oxford: Wiley BlackWell, 2009.

2. Kosim MS, Yunanto A, Dewi R, Sarosa GI, Usman A. Buku ajar neonatologi. Edisi ke-1: Jakarta: Badan Penerbit IDAI, 2010.

3. Boer JMA, Van B, Hoogervorst, Luijten, Vries De. Effect of maternal diet during pregnancy on birth weight of the infant. Centre for nutrition and health. RIVM Report. Bilhoven: The Netherland of national institute for public health and the environment,2009.

4. Guardamagna O, Abello F, Cagliero P, Lughetti L. Impact of nutrition since early life on cardiovascular prevention. Ital J Pediatr. 2012;38:73.

5. Nutrition during pregnancy, Nutrient needs during pregnancy.http://www.foxitsoftware.com

6. Jansson N, Nilsfelt A, Gellerstedt M, Wennergren M, Rossander-Hulthén L, Powell TL, Jansson T. Maternal hormones linking maternal body mass index and dietary intake to birth weight. Am J Clin Nutr 2008; 87:1743-9.

7. Akram SK, Carlsson-Skwirut C, Bhutta ZA, Soder O. Placental IGF-I, IGFBP-1, zinc, and iron, and maternal and infant anthropometry at birth. Acta Paediatr 2011; 100:1504-9.

8. Moyer-Mileur LJ, Slater H, Thomson JA, Mihalopoulos N, Byrne J, Varner MW. Newborn adiposity measured by plethysmography is not predicted by late gestation twodimensional ultrasound measures of fetal growth.J Nutr. 2009;139(9):1772-8

9. Halhali A, Tovar AR, Torres N, Bourges H, Garabedian M, Larrea F. Preeclampsia is associated with low circulating levels of IGF-I and 1,25-dihydroxyvitamin D in maternal and umbilical cord compartments. J Clin Endocrinol Metab:2000;85:1828-33

10. Diaz E, Halhali A, Luna C, Diaz L, Avila E, Larrea F. Newborn birth weight correlates with placental zinc, umbilical IGF-I and leptin levels in preeclampsia. Arch Med Res 2002;330:40-7. 